\title{
Research on the Quality Improvement of Education Talent Cultivation in China's Higher Engineering
}

\author{
Jie Liu \\ Office of Academic Affairs Jiang Su University \\ Zhenjiang, China \\ liujie@ujs.edu.cn
}

\begin{abstract}
Under the current development situation of new technology, new industry and new economic, the core requirements of higher engineering education with new ideas, structures, mode, quality and system give a new connotation to the quality of higher engineering education since China becomes the full member of Washington Accord. Following the new development concept, university-enterprise cooperation becomes an important means of training student. The effect of it is closely related to the engineering education quality. In view of the cooperation model between university and enterprises abroad, this paper points out the significant meanings for improving the engineering innovative ability to break through the bottleneck of engineering quality improvement in university. In addition, this paper puts forward to establish the win-win mechanism between university and enterprises, because it is not only the cooperative foundation, but also an important impetus for carrying out the unive rsity-enterprise cooperation cultivation model.
\end{abstract}

Keywords-Higher engineering education; Universityenterprise cooperation; Engineering practice innovation ability. sino-foreign comparison

\section{ANALYSIS THE BOTTLENECK OF HIGHER ENGINEERING QUALITY IMPROVEMENT}

Admittedly, compared with other disciplines, the quality of higher engineering education largely depends on the students' ability of innovation in engineering practice, which relies on the depth and effect of cooperation between universities and enterprises. Therefore, the deep involvement of industry enterprises in the training process has a great impact on the cultivation of engineering talents. While, in terms of the domestic engineering talents cultivation, the engineering practice, curriculum development and teaching material compilation present a difficult or reluctant state, becoming the bottleneck of quality improvement of engineering talents.

In essence, the restrictive factors of university enterprise cooperation lie in the lack of stickiness and active cooperation awareness between university and enterprises. In order to solve the problem, the managements in high university make relevant policies to attract industry enterprise to concern the process of engineering education, aiming to improving the quality of talent training. However, the effect is not obvious as expected. One of the main factor is the implementation deviation in the process, which impedes the classroom teaching and reduces the teaching enthusiasm. In current, curriculum design philosophy based on graduation requirements is not reflected sufficiently. On the one hand, the university has insufficient reasons to encourage enterprises to deep participate in the cultivation process because cultivating student is not the enterprises' obligation. On the contrary, accepting the trainee may add the enterprises' responsibility of safety. On the other hand, as an experienced technology or management, there is not a clear-cut security mechanism for floating personnel of university and enterprise. These factors impede the university-enterprises cooperation and affect the cooperation model, cooperation content and cooperation effectiveness, causing an unsatisfactory result.

II. THE MODEL REFERENCE OF FOREIGN UNIVERSITY ENTERPRISE COOPERATION

It is of great reference significance to analyze the cultivation mode of cooperation between foreign universities and enterprises.

\section{A. American University-enterprise Cooperation}

The United States imitated the British and French engineer training patterns, and then borrowed the German model. The teaching methods of engineering universities are very flexible. Besides the traditional classroom teaching methods, it also includes cooperative learning, project learning, experimental design and online learning, etc. In the mode of cultivating talents in school-enterprise cooperation, we have gradually innovated a variety of modes from "cooperation education project" to "parallel mode", "alternative mode" and "dual mode". The government has put technology and engineering education in an important strategic position in relation to national security. What's more, the engineering and engineering education is incorporated into the national science foundation. On this basis, some enterprises and engineering universities form an alliance, and develop new products cooperatively, realizing the win-win cooperation. In addition, the system of registered engineers in the United States, including education, qualifying examinations and work experience, ties universities more closely to enterprises.

\section{B. German University-enterprise Cooperation}

Germany is known for the "dual system" of school-enterprise training mode jointly, which means both enterprise and university undertake the student training. The dual system model realizes the connection in two different environment and operation system of university and the enterprise, which is the internationally recognized university-enterprise cooperation model. Through the legislation, the government clarifies the responsibilities and obligations of the government, enterprises and universities in 
the internship of engineering students, as well as the principles and methods. At the same time, economic leverage is performed to promote school-enterprise cooperation. In addition, the university attaches importance to the cultivation of students' engineering practice ability, and the practice session accounts for about $2 / 3$ of the total class time, so as to strengthen the practice teaching. Engineering education practice is not only a professional degree, but also a professional qualification system of "diploma engineers" that blends of engineering education in social development. The model reflects the strong vocational adaptability of students.

\section{Japanese university-enterprise cooperation}

Japan promotes the policy of "experiential employment", which introduces the cooperation research field into education, emphasizing the social responsibility of enterprises to reconstruct the university-enterprise relationship. In terms of university-enterprise cooperation to cultivate talents, the universities employ enterprise engineering and technical personnel to participate in students training, to guide the teaching design and teaching reform. Therefore, the enterprises also strengthen the intervention of talent training, and think that the professional view, occupational adaptation ability, ethical behavior of students cannot live without the participation of enterprises.

Considering the university-enterprise cooperation model abroad, we can draw the following conclusion: the win-win results during university-enterprise cooperation are effective to promote enterprises to undertake the task of cultivating engineering talents. What's more, the government makes policies to clarify the responsibilities and obligations of the two parties, and to compensate the economic losses of enterprises caused by students training by tax reduction policies. In my opinion, the multi-win results produced by university-enterprise cooperation are the key and foundation for the smooth and healthy development of school-enterprise cooperation.

Many of the questionnaires and interviews reveal that the domestic is not creating a good environment for cultivating the engineering innovation ability. Some external factors, such as deficient government leading mechanism, deficient dynamic mechanism of universities, deficient incentive policy of enterprise, and so on cause the sluggish university-enterprise cooperation. Meanwhile, a win-win mechanism is the intrinsic influencing factors of university-enterprise cooperation achievements. Universities have the rich resources of teaching and scientific research, and enterprises own good equipment and training condition. Because of lacking effective communication and exchanges, mutual confidence, the sharing mechanism has not been established yet, which restricts resources integration and sharing and limit the enterprises' investment in training students' engineering practical ability. Due to the absence of such a win-win mechanism, both universities and enterprises concerns about the return on investment. Therefore, the insufficient investment degree of the university leads to the inactive participation of enterprises, causing the insufficient cultivation of students' engineering practice innovation ability. In current, enterprises just provide a place of understanding practice, production practice and professional training, rather than play the dominant role and cultivate the student's ability of engineering practice.

\section{THE URGENT IMPROVEMENT OF INNOVATION ABILITY FOR STUDENTS OF NEW AGE}

China as a large country of higher engineering education is always devoted to become a powerful nation of higher engineering. In recent years, the national strategic deployment revolves around the higher engineering education, quality improvement of the engineering talent training, aiming to accelerate the process of becoming a powerful nation of higher engineering.

At first, the ministry of education issued "several opinions on the implementation of education to cultivate outstanding engineers plan" (high [2011] no. 1) on January 8, 2011, launched "outstanding engineers training plan", aimed at "geared to the needs of the industry, the world and the future, to train a large number of strong innovation ability, to cultivate various types of engineering and technical personnel that adapt the development needs of economic and social".

Secondly, the General Office of the State Council issued "Suggestions on deepening the reform of innovation and entrepreneurship education in Colleges and Universities" in May 2015, The overall goal is to deepen the reform of innovation and entrepreneurship education in Colleges and universities, to popularize innovation and entrepreneurship education, to carry out innovative and entrepreneurial education as the grasp, to establish an innovative and innovative education system and to improve the quality of personnel training.

Thirdly, China Engineering Education Professional Certification Association was established in October 2015. It is a national social organization consisting of institutions and individuals related to engineering education. and is mainly responsible for the organization and implementation of engineering education accreditation by carrying out the professional certification of engineering education to improve the engineering education quality. In June 2016, China formally joined the most influential engineering education degree mutual recognition agreement--the Washington agreement. According to the development requirements of Chinese engineering education reform, the association will improve the system of engineering education certification to better ensure the quality of engineering education training, to improve the adaptability of engineering education for the industrial development, ultimately making greater contribution to the national economic and social development and industrial construction.

Fourthly, the new engineering concept was proposed in 2016. After discussion, research and demonstration, the Ministry of high education department formally launched the "new engineering" program in 2017, has formed "Fudan consensus", "big action", "Beijing guide" and other guidance document. With the implementation of the new engineering plan, the higher engineering education paradigm has changed. Aihua $\mathrm{Wu}$, one of the numbers of the ministry of education, proposed the core content of the new engineering department, new ideas, new structures, new models, new quality and new 
system[1]. "Integration innovation" has become a new engineering education paradigm[2].

From "excellent engineer training plan" to "engineering education professional certification", "innovation and entrepreneurship education reform", and "new engineering" education, all of them focus on the improvement of engineering practice innovation ability of higher engineering talents, which all take university-enterprise cooperation as an indispensable link to improve the quality of Engineering Talents. The "excellent plan" will be one of the implementation principles of the industry. The professional certification of engineering education is one of the standard items for training goals, which is an important reference for the formulation of the students' graduation requirements. What's more, the determination of the training target is exactly the response of the industry needs[3]. Strengthening the practice of innovation and entrepreneurship is one of the main tasks of deepening the reform of innovation and entrepreneurship education in Colleges and universities[4]. Under the background of a new round of science, industry, and economic transformation, new engineering is faced with the new opportunity, new task and new challenge. "Asking the industry to build a professional" and "asking for the content of technological development and reform" reflect that industry plays an important role in the construction of new engineering[5]. Industries try to establish engineering education system that adapts to new technology, new industry and new economic development.

As an important part of training students' engineering practice ability in engineering education, the quality of university-enterprise cooperation affects the quality of personnel training directly.

\section{ANALYSIS OF CULTIVATING TALENTS MODE BY COOPERATION BETWEEN UNIVERSITY AND ENTERPRISE}

To sum up, the university-enterprise cooperation is urgent to train talents and break through the bottleneck of improving the creative ability of students' engineering practice. In order to promote the cooperation between university and enterprise, we need to think deeply and actively to promote the healthy and sustainable development of school enterprise cooperation.

Firstly, we must establish a long-term and close cooperation between schools and enterprises. Efforts should be made to establish a cooperative relationship with the enterprise on the strategic level, to carry out the service functions of enterprises in the process of specific and realistic cooperation. Specifically, communication and publicity should be strengthen to promote mutual understanding between enterprises and universities, to obtain the sincere approval and support of the enterprise. Secondly, universities should sign the win-win joint training protocol between enterprises and universities, and promise to serve for the enterprise wholeheartedly in the aspects of undergraduate recruitment, staff training and project consultation. Thirdly, universities should make use of all the social relations to contact with practice units extensively, to strengthen the connection with practice units, and to establish a group of stable practice points and practice bases. In addition, universities should pay more attention to construction of enterprise practice base. The construction of practice base will provide talents for enterprises and help the enterprise to publicize. Especially in the background of new engineering, the new engineering department has the characteristics of "leading", "wide", "forward looking", "cross", "open" and "practical"[6]. Building a "learning factory" model to build a cooperative education platform is one of the measures to solve the innovation of engineering education.

In addition, universities should explore the incentive mechanism of professional teachers. Ultimately, the teacher's input is the key factor that decides the quality of university-enterprise cooperation except for enterprise cooperation. Therefore, colleges and universities must actively explore, guide and encourage professional teachers to work hard in joint efforts of university and enterprise, for example, the implementation of new incentive policies in the appointment of teachers' titles, performance assessment and so on, or increasing the evaluation of the professional ability of engineering teachers from the main emphasis on theoretical research and publication of papers to more emphasis on the effectiveness of engineering education and engineering practice. What's more, universities should encourage teachers to take part in the training of engineering talents in schools and enterprises. The training of engineering talents will be appraised as assessment indicators of school enterprise cooperation.

In the process of training students in university-enterprise cooperation, university and enterprise eliminate the concern among the students collectively based on the foundation of cooperation and mutual benefits. In addition, government's macro-control, Policy support and guarantee can sustain the healthy development of university-enterprise cooperation and improve the innovative ability of students, realizing the a powerful dream of higher engineering education as soon as possible.

\section{ACKNOWLEDGEMENT}

The author gratefully acknowledge the financial support from Research projects of postgraduate research in Jiangsu Universities of 2013 'Research on the difficulty of deep participation in advanced engineering talents training"(CXLX13-693), and Jiangsu province education science planning projects in 13th Five-Year in 2015 "Analysis of the development and implementation effect of Engineering Education Accreditation in China"(D/2015/1/25)

\section{REFERENCES}

[1] Aihua Wu et al,. Speed up the development and construction of new engineering, and actively adapt to and lead the new economy. Research on Higher Engineering Education, 2017(1):1-9. (In Chinese)

[2] Maoguo Li et al,. The paradigm of Engineering Education: from regression engineering to integration innovation. China High Education Research, 2017(6):30-36. (In Chinese)

[3] The Secretariat of the China Association for engineering education certification. Engineering education certification: work guide, 2018:21-23. (In Chinese)

[4] Office of the State Council. Suggestions on deepening the reform of innovation and entrepreneurship education in Colleges and Universities. Ministry of Education of the People's Republic of China. 
[http://www.moe.gov.cn/s78/A08/moe_745/201704/t20170412_302427. [http://www.moe.gov.cn/s78/A08/moe_745/201506/t20150611_189999. html] (accessed 2018.4.15). (In Chinese)

[5] Higher Education Department. "New engineering" construction action line ("big action"). Ministry of Education of the People's Republic of China.

[6] Ji Zhao et al, Construction of new engineering and innovation of Engineering Education. Research on Higher Engineering Education, 2017(5):13-17. (In Chinese) 